\title{
Mixed Connective Tissue Disease
}

National Cancer Institute

\section{Source}

National Cancer Institute. Mixed Connective Tissue Disease. NCI Thesaurus. Code C84892.

An autoimmune overlap syndrome characterized by the presence of symptoms of systemic lupus erythematosus, systemic scleroderma, and polymyositis. 